\title{
CDP-Choline Effect on Arthritis Model in Rat
}

\section{Mehranfard $\mathrm{D}^{1 *}$ and Hamurtekin $\mathrm{E}^{2}$}

${ }^{1}$ College of Pharmacy, Nova Southeastern University, USA

${ }^{2}$ Faculty of Pharmacy, Eastern Mediterranean University, Cyprus

*Corresponding author: Danial Mehranfard, Pharm.D. College of Pharmacy, Nova

\section{Mini Review}

Volume 3 Issue 1

Received Date: March 04, 2019

Published Date: March 08, 2019

DOI: $10.23880 /$ oajpr-16000174

Southeastern University, FL, USA, Tel: +1(786)409-9084; Email: dm.daniel73@gmail.com

\section{Abstract}

CDP-choline is a naturally occurring endogenous nucleotide, which after administration rapidly metabolizes to choline (which is a natural $\alpha 7 \mathrm{nAChR}$ selective Agonist) and cytidine/uridine. In the body, Choline promotes several biological functions such as acting as a precursor of neurotransmitter Acetylcholine. As a result of choline availability, Ach synthesis will also increase. It is well known that nervous system under the cholinergic anti-inflammatory pathway concept has an important role in this inflammatory response mainly through $\alpha 7$ sub-unit of nicotinic acetylcholine receptor which is expressed by different types of immune cells, including macrophages. This pathway conducts its role mainly through stimulation of vagus nerve results in the production of Ach which is an $\alpha 7 \mathrm{nAChR}$ Agonist. Therefore, in the light of above studies we can hypothesize that exogenously administration of CDP-Choline results in enhancement of Choline and subsequently Ach level in plasma that could antagonize $\alpha 7 \mathrm{nAChR}$ present on various immune cells, such as macrophages and FLS; which may exert analgesic effect via decreasing pro-inflammatory cytokines production and decreasement of inflammation in arthritis pain model in rat.

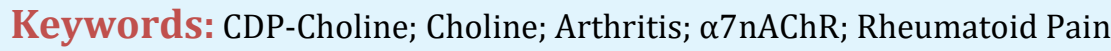

\section{Mini Review}

CDP-choline (citicholne, cytidine 5'-diphosphocholine) is a naturally occurring endogenous nucleotide, [1] which is mainly synthesized by CDP-choline pathway in the body [2]. CDP-choline beneficial role in improving mental performance among the Alzheimer disease patients [3], prevention of memory impairment [4], stroke and Other CNS Disorders [5] due to many studies has already been stablished.

CDP-choline following Orally, IV or intracerebroventricularly (i.c.v) administration rapidly metabolize to choline and cytidine/uridine $[1,6]$ which leads to increased plasma and tissue concentration of these metabolites [6]. It has been shown that elevation in the plasma level of choline will also increase its level in the brain $[7,8]$. In the body Choline promote several biological functions such as acting as a precursor of neurotransmitter Acetylcholine [9] as a result of choline availability, Ach synthesis will also increase [6,7,10] subsequently increasing in Ach synthesis will also enhance the cholinergic neurotransmission activity $[6,11]$ Centrally and peripherally enhanced cholinergic neurotransmission activity mediates many effects of CDPcholine $[12,13]$. 


\section{Open Access Journal of Pharmaceutical Research}

Studies have discovered an anti-inflammatory role for the parasympathetic nervous system through inhibition of TNF- $\alpha$ release [6,14]. It is well known that nervous system under the concept of cholinergic antiinflammatory pathway (CAP) has an important role in this inflammatory response [15]. This pathway conducts its role mainly through stimulation of vagus nerve results in production of Ach, the principle vagal neurotransmitter $[14,16,17]$ that interacts with membrane of nicotinic acetylcholine receptor (nAChR) family; specifically the $\alpha 7$ sub-unit of nicotinic acetylcholine receptor $(\alpha 7 \mathrm{nAChR})$ $[15,17]$ which is expressed by different types of immune cells, including macrophages (responsible for secreting pro-inflammatory cytokines including TNFa, IL-1[18], which both cytokines are actively produced at the local inflammation area [19]) [17,19] results in significantly and concentration-dependently decreasment of TNF production [20], and significantly attenuation of the releasement of other pro-inflammatory cytokines including interleukin (IL)-1beta, IL-6 and IL-18 [14].

Choline which is one of the hydrolism products of CDP-Choline is a natural $\alpha 7 \mathrm{nAChR}$ selective Agonist [6,21-23] and from different researches we know that $\alpha 7 \mathrm{nAChR}$ selective Agonists has been shown to have antiinflammatory activity; [24-26] also choline is able to decrease TNF release dose dependently and this effect requires $\alpha 7 \mathrm{nAChR}$-mediated signaling [22] (TNF increase inflammation by activating the release of proinflammatory mediators such as IL-1, HMGB1, nitric oxide [20]).

Due to different studies we also know that intracerebroventricularly injection of CDP-choline dose and time dependently has antinociceptive effects which mainly mediated by activation of $\alpha 7 \mathrm{nAChR}$. $[6,27,28]$.

So, in the light of the above studies we can hypothesize that exogenously administration of CDP-Choline dose and time dependently results in enhancement of Choline and subsequently Ach level in plasma that could antagonize $\alpha 7 \mathrm{nAChR}$ present on various immune cells, including monocytes, macrophages, $\mathrm{T}$ and $\mathrm{B}$ lymphocytes, dendritic cells and FLS; which may exert analgesic effect via decreasing pro-inflammatory cytokines production and decreasement of inflammation.

According to our knowledge up on until now there is no research available which directly measure the levels of pro-inflammatory cytokines (such as TNFa, IL-1 and IL-6) and inflammation after exogenously injection of CDPcholine and investigate its possible role as an analgesic in arthritis pain model in rat.

\section{References}

1. Weiss GB (1995) Metabolism and actions of CDP choline as an endogenous compound and administered exogenously as citicoline. Life Sci 56(9): 637-660.

2. Jambou R, El-Assaad F, Combes V, Grau GE (2009) Citicoline (CDP-choline): What role in the treatment of complications of infectious diseases. Int J Biochem Cell Biol 41(7): 1467-1470.

3. Cacabelos R1, Caamaño J, Gómez MJ, FernándezNovoa L, Franco-Maside A, et al. (1996) Therapeutic Effects of CDP-Choline in Alzheimer's DiseaseCognition, Brain Mapping, Cerebrovascular Hemodynamics, and Immune Factorsa. Ann N Y Acad Sci 777(1): 399-403.

4. Teather LA, Wurtman RJ (2005) Dietary CDP-choline supplementation prevents memory impairment caused by impoverished environmental conditions in rats. Learn Mem 12(1): 39-43.

5. Adibhatla RM, Hatcher JF (2005) Cytidine 5'diphosphocholine (CDP-choline) in stroke and other CNS disorders. Neurochem Res 30(1): 15-23.

6. Gurun MS, Parker R, Eisenach JC, Vincler M (2009) The Effect of Peripherally Administered CDP-Choline in an Acute Inflammatory Pain Model: The Role of $\alpha 7$ Nicotinic Acetylcholine Receptor. Anesth Analg 108(5): 1680-1687.

7. Haubrich DR, Wang PFL, Clody DE, Wedeking PW (1975) Increase in rat brain acetylcholine induced by choline or deanol. Life Sci 17(6): 975-980.

8. Hirsch M, Wurtman R (1978) Lecithin consumption increases acetylcholine concentrations in rat brain and adrenal gland. Science 202(4364): 223-225.

9. Blusztajn JK (1998) Choline, a vital amine. Science.281(5378): 794-795.

10. Buyukuysal R, Ulus I, Aydin S, Kiran B (1995) 3, 4Diaminopyridine and choline increase in vivo acetylcholine release in rat striatum. Eur J Pharmacol 281: 179-185.

11. Hamilton DS, Tyler N, Tyler R, Raeuchle SK, Holtz MH, et al. (2002) Reactivation of mature oil fields through advanced reservoir characterization: A case history of 


\section{Open Access Journal of Pharmaceutical Research}

the Budare field, Venezuela. Am Assoc Pet Geol Bull 86(7): 1237-1262.

12. Savci V, Goktalay G, Cansev M, Cavun S, Yilmaz MS, et al. (2003) Intravenously injected CDP-choline increases blood pressure and reverses hypotension in haemorrhagic shock: Effect is mediated by central cholinergic activation. Eur J Pharmacol. 468(2): 129139.

13. Cansev M, Yilmaz MS, Ilcol YO, Hamurtekin E, Ulus IH (2007) Cardiovascular effects of CDP-choline and its metabolites: involvement of peripheral autonomic nervous system. Eur J Pharmacol 577(1-3): 129-142.

14. Tracey KJ, Borovikova LV, Ivanova S, Zhang M, Yang $\mathrm{H}$, et al. (2000) Vagus nerve stimulation attenuates the systemic inflammatory response to endotoxin. Nature 405(6785): 458-462.

15. Maanen MA van, Stoof SP, LaRosa GJ, Vervoordeldonk MJ, Tak PP (2010) Role of the cholinergic nervous system in rheumatoid arthritis: aggravation of arthritis in nicotinic acetylcholine receptor $\alpha 7$ subunit gene knockout mice. Ann Rheum Dis 69(9): 1717-1723.

16. Koopman FA, Schuurman PR, Vervoordeldonk MJ, Tak PP (2014) Vagus nerve stimulation: A new bioelectronics approach to treat rheumatoid arthritis? Best Pract Res Clin Rheumatol 28(4): 625635.

17. van Maanen MA, Vervoordeldonk MJ, Tak PP (2009) The cholinergic anti-inflammatory pathway: towards innovative treatment of rheumatoid arthritis. Nat Rev Rheumatol 5(4): 229-232.

18. Wessler I, Kilbinger $\mathrm{H}$, Bittinger $\mathrm{F}$, Unger $\mathrm{R}$, Kirkpatrick CJ (2003) The non-neuronal cholinergic system in humans: Expression, function and pathophysiology. Life Sci 72(18-19): 2055-2061.

19. Dinarello CA (2000) Proinflammatory cytokines. Chest 118(2): 503-508.

20. Pavlov VA, Wang H, Czura CJ, Friedman SG, Tracey KJ (2003) The Cholinergic Anti-inflammatory Pathway:
A Missing Link in Neuroimmunomodulation. Mol Med 9(5-8): 125-134.

21. Papke RL, Bencherif M, Lippiello $P$ (1996) An evaluation of neuronal nicotinic acetylcholine receptor activation by quaternary nitrogen compounds indicates that choline is selective for the alpha 7 subtype. Neurosci Lett 213(3): 201-204.

22. Parrish WR, Rosas-Ballina M, Gallowitsch-Puerta $M$, Ochani M, Ochani K, et al. (2008) Modulation of TNF release by choline requires alpha7 subunit nicotinic acetylcholine receptor-mediated signaling. Mol Med 14(9-10): 567-574.

23. Alkondon M, Pereira EFR, Cortes WS, Maelicke A, Albuquerque EX (1997) Choline is a selective agonist of a7 nicotinic acetylcholine receptors in the rat brain neurons. Eur J Neurosci 9(12): 2734-2742.

24. Van Maanen MA, Lebre MC, Van Der Poll T, LaRosa GJ, Elbaum D, et al. (2009) Stimulation of nicotinic acetylcholine receptors attenuates collagen-induced arthritis in mice. Arthritis Rheum 60(1): 114-122.

25. Waldburger JM, Boyle DL, Pavlov VA, Tracey KJ, Firestein GS (2008) Acetylcholine regulation of synoviocyte cytokine expression by the $\alpha 7$ nicotinic receptor. Arthritis Rheum 58(11): 3439-3449.

26. Bodnar AL, Cortes-Burgos LA, Cook KK, Dinh DM, Groppi VE, et al. (2005) Discovery and Structure-Activity Relationship of Quinuclidine Benzamides as Agonists of $\alpha 7$ Nicotinic Acetylcholine Receptors. J Med Chem 48(4): 905-908.

27. Hamurtekin E, Bagdas D, Gurun MS (2007) Possible involvement of supraspinal opioid and GABA receptors in CDP-choline-induced antinociception in acute pain models in rats. Neurosci Lett 420(2): 116121.

28. Hamurtekin E, Sibel Gurun M (2006) The antinociceptive effects of centrally administered CDPcholine on acute pain models in rats: The involvement of cholinergic system. Brain Res 1117(1): 92-100. 